\title{
Experimental Investigation Of Effective Utilization of Plastic Waste in Concrete Beams
}

\author{
Nitheesh Kumar M.R ${ }^{1}$, Sri Ruban .D ${ }^{2}$ \\ ${ }^{1}$ M.E Structural Engineering, Gnanamani College of Engineering, Namakkal, Tamilnadu, India \\ ${ }^{2}$ Assistant Professor, Department of Civil Engineering, Gnanamani College of Engineering, Namakkal, Tamilnadu, India
}

\begin{abstract}
Plastic waste is a growing concern in our day to day life. Although recently there has been a slight decrease in plastic production, this is unlikely to be maintained. Plastics are highly useful material and its applications are expected to increase as more new products and plastics are developed to meet demand. The impacts of plastic waste on our health and the environment are only just becoming apparent. Most of our knowledge is around plastic waste in the marine environment, although there is research that indicates plastic waste in landfill and in badly managed recycling systems could be having an impact, mainly from the chemicals contained in plastic.
\end{abstract}

Keywords: Compressive strength, Fine aggregates, Plastic wastes, Split tensile strength

\section{Introduction}

Plastic waste recycling can provide an opportunity to collect and dispose of plastic waste in the most environmentally friendly way and it can be converted into a resource. In most of the situations, plastic waste recycling could also be economically viable, as it generates resources, which are in high demand. Plastic waste recycling also has a great potential for resource conservation and GHG emissions reduction, such as producing diesel fuel from plastic waste. This resource conservation goal is very important for most of the national and local governments, where rapid industrialization and economic development is putting a lot of pressure on natural resources.

The use of plastic is getting increased even several regulations to control the use are in force. One way to control the ill effect of the plastic is to effective usage of the waste plastic. Thinking in this direction the possibility of the use of plastic as a raw material for the construction industry was planned to explore through this project. Based on that, a methodology was developed to study the use of plastic (a) as soil stabilization purpose (b) additive to the bitumen and the addition of plastic in strip form to the concrete. Plastic can be added as one of the constituent's materials of concrete,to improve the certain properties of concrete. Also, it can be used along with soil as a stabilizer and with bitumen improving its properties.

\section{Objectives}

The main objectives of the study are as follows:

1) To recycle plastic waste effectively

2) To study the feasibility of plastic as soil stabilizer

3) To conduct a study on CBR behaviour of plastic reinforced soil

4) To study compressive strength of concrete having plastic fibre

5) To study the properties of bitumen modified with plastic

\section{Testing Programme}

In the present study various tests on material such as soil, cement, fine aggregate, coarse aggregate were performed as per the Indian Standards.

\section{A. Soil}

The soil sample was collected from the premises of college. The properties of soil investigated are presented in table 1.

Table 1: Properties of Soil

\begin{tabular}{|c|c|c|}
\hline Sl no & Property & Value \\
\hline 1 & Bulk density & $1.72 \times 10-3 \mathrm{~g} / \mathrm{cc}$ \\
\hline 2 & Dry density & $1.456 \mathrm{~g} / \mathrm{cc}$ \\
\hline
\end{tabular}

\section{1) Compaction test of soil}

Objective of the test is to determine the moisture dry density relation for a given soil using constant comp active effort andsubsequently findthe maximum dry density and the optimum water content.

\section{2) Grain Size Analysis}

The object of this experiment is to determine grain size distribution of coarse grained soil by sieving. Soils usually consist of particles of different sizes in varying quantities. The graph showing the compaction curve of the dry density $\mathrm{v} / \mathrm{s}$ water content in figure 1 and particle distribution size curve of percentage finer versus sieve size in figure 2 . 


\section{International Journal of Science and Research (IJSR) \\ ISSN (Online): 2319-7064}

Index Copernicus Value (2015): 78.96 | Impact Factor (2015): 6.391

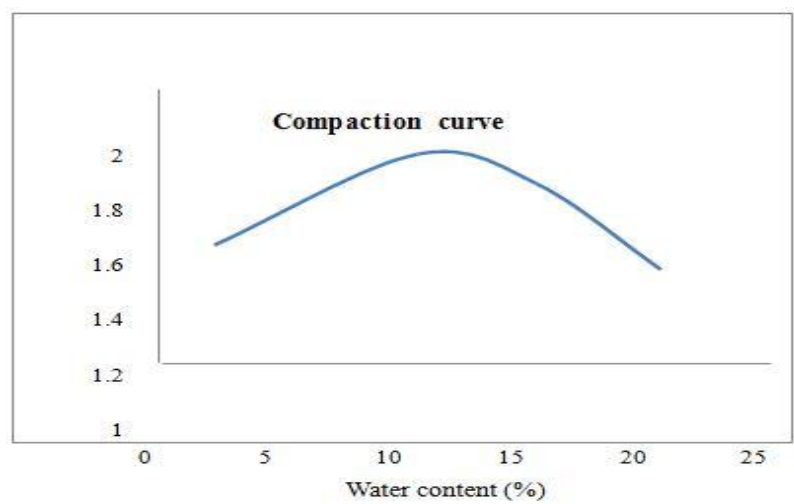

Figure 1: Dry density v/s water content

Particle size distribution curve

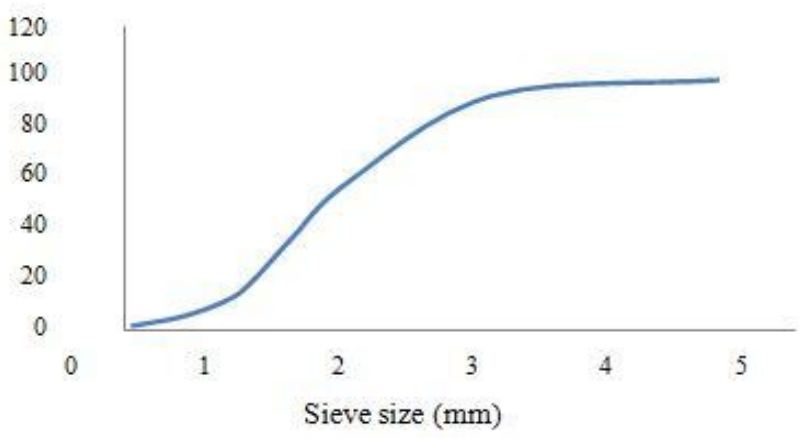

Figure 2: Percentage finer versus sieve size

\section{B. Cement}

Ordinary Portland cement of 53 grade was purchased from the local supplier and used throughout this project. The properties of cement used in the investigation are presented in table 2 .

Table 2: Properties of Cement

\begin{tabular}{|c|c|c|}
\hline Sl no & Property & Value \\
\hline 1 & Specific Gravity & 3.15 \\
\hline 2 & Fineness & $1 \%$ \\
\hline 3 & Initial setting & $30 \mathrm{~min}$ \\
\hline 4 & Compressive strength & 58.5 \\
\hline 5 & Soundness & 3.67 \\
\hline
\end{tabular}

\section{Fine Aggregates}

Fine aggregate is a material passing through an IS sieve that is less than $4.75 \mathrm{~mm}$.Usually, natural sand is used as a fine aggregate at places where natural sand is not available crushed stone is used as a fine aggregate. The sand used for the experimental work was locally procured and conformed to grading zoneII.The properties of fine aggregates are given in table 3 .

Table 3: Properties Of Fine Aggregates

\begin{tabular}{|c|c|c|}
\hline Sl no & Property & Value \\
\hline 1 & Specific gravity & 2.6 \\
\hline 2 & Water absorption & $0.51 \%$ \\
\hline 3 & Free moisture & $2 \%$ \\
\hline
\end{tabular}

\section{Coarse aggregates}

The materials which are retained on $4.75 \mathrm{~mm}$ sieve are calledcoarse aggregate. The broken stone is generally used as a coarse aggregate. The nature of work decides the maximum size of coarse aggregate. Locally available coarse aggregate having the maximum size of $20 \mathrm{~mm}$ was used in the present work. The properties of coarse aggregates are given in the table 4.

Table 4: Properties Of Coarse Aggregates

\begin{tabular}{|c|c|c|}
\hline S. No & Property & Value \\
\hline 1 & Specific Gravity & 7.5 \\
\hline 2 & Water absorption & $0.303 \%$ \\
\hline
\end{tabular}

\section{E. Water}

Water is an important ingredient of concrete as it actively participates in the chemical reaction with cement. Since it help to form the strength giving cement gel, the quantity and quality of water is required to be looked in to very carefully. Portable water is generally considered satisfactory. In present investigation, tap water was used for both mixing and curing purpose.

\section{Preparation of Specimen}

Based on the above results the water quantity, cement, fine aggregate and coarse aggregate required for design mix of M30 were calculated based on the procedure given in IS code method in IS 456:2009. The final mix ratio was $0.42: 1: 1.019: 2.75$ with water cement ratio of 0.42 . The measurement of materials was done by weight using electronic weighing machine. Water was measured in volume. Concrete was placed in moulds in layers. The cast specimens were removed from moulds after 24 hours and the specimens were kept for water curing.

\section{A. Mix proportion of plastic waste}

Mix proportions were made for fine aggregate and were replaced with waste plastic. The proportions of fine aggregate replaced range from $0 \%$ to $20 \%$ mix proportions are given. Mix proportion of plastic waste is given in Table 5

Table 5: Mix Proportion of Plastic Waste

\begin{tabular}{|l|c|c|c|c|}
\hline \multicolumn{1}{|c|}{ Materials } & $\mathrm{P}_{5}$ & $\mathrm{P}_{10}$ & $\mathrm{P}_{15}$ & $\mathrm{P}_{20}$ \\
\hline Cement $\left(\mathrm{kg} / \mathrm{m}^{3}\right)$ & 456.24 & 456.24 & 456.24 & 456.24 \\
\hline Plastic waste $(\%)$ & 5 & 10 & 15 & 20 \\
\hline Sand $\left(\mathrm{kg} / \mathrm{m}^{3}\right)$ & 442.10 & 418.83 & 396.26 & 372.29 \\
\hline Coarse aggregate $\left(\mathrm{kg} / \mathrm{m}^{3}\right)$ & 1256.56 & 1256.56 & 1256.56 & 1256.56 \\
\hline Water $($ liters $)$ & 187.79 & 187.79 & 187.79 & 187.79 \\
\hline
\end{tabular}

Where,

$\mathrm{P}_{5}$ - weight of crumb at 5\%

$\mathrm{P}_{10}$ - weight of crumb at $10 \%$

$\mathrm{P}_{15}$ - weight of crumb at $15 \%$

$\mathrm{P}_{20}$ - weight of crumb at $20 \%$ 


\section{International Journal of Science and Research (IJSR) \\ ISSN (Online): 2319-7064 \\ Index Copernicus Value (2015): 78.96 | Impact Factor (2015): 6.391}

\section{Testing of Specimens}

For each batch of concrete, 3 cubes of $150 \mathrm{~mm} \times 150 \mathrm{~mm}$ $\mathrm{x} 150 \mathrm{~mm}$ size were tested to determine compressive strength of concrete, 3 cylinders of $150 \mathrm{~mm}$ diameter and $300 \mathrm{~mm}$ length were tested to determine split tensile strength of concrete.

\section{Results and Discussions}

Table 6: Experimental Test Results at 28 Days Curing

\begin{tabular}{|c|c|c|}
\hline $\begin{array}{c}\text { Percentage of plastic } \\
\text { waste used (\%) }\end{array}$ & $\begin{array}{c}\text { Compressive } \\
\text { strength(N/mm2) }\end{array}$ & $\begin{array}{c}\text { Split tensile } \\
\text { strength (N/mm2) }\end{array}$ \\
\hline 0 & 30 & 3.42 \\
\hline 5 & 30.1 & 3.35 \\
\hline 10 & 30.1 & 3.35 \\
\hline 15 & 31.4 & 3.38 \\
\hline 20 & 29.9 & 3.30 \\
\hline
\end{tabular}

\section{Conclusions}

- The soil sample with aspect Ratiol and percentageof plastic 0.25 showed maximum CBR value.

- CBR value was $20.6 \%$ higher than reference specimen.

- Compressive strength of concrete with plastic content of $0.5 \%$ having aspect Ratio 30 shows $5 \%$ higher strength than the reference mix.

- Split tensile strength of concrete with plastic content of $0.5 \%$ having aspect ratio 30 shows $24 \%$ higher strength than the reference mix.

- Addition of plastic improves the properties of bitumen like softening pointand ductility.

\section{References}

[1] Pragyan Bhattarai, "Engineering behavior of soilrforced with plastic strips",International Journal of Civil, Structural, Environmental and Infrastructure EngineeringResearch and Development (IJCSEIERD), Vol. 3, Issue 2, Jun 2013,pp: 83-88

[2] Mukherjee S. P. and Chakrabarti Sankar, "Up graation ofgeotechnical parameters bywaste plastic admixture in soil", Journal of Environmental Research And DevelopmentVol. 8,Issue 3, January-March 2014, pp: 759765

[3] Maha Hatem N Saif, "Behavior of soils strengthened by plastic waste materials"International Journal of Engineering and Development, Vol. 17, Issue 4, October 2013,pp: 182-194

[4] Megnath Neopaney, "Stabilization of soil by using plastic wastes", International Journalof Emerging trends in Engineering and Development, Vol. 2, Issue 2, March2012, pp:461-466

[5] M. Sulyman, J. Haponiuk, and K. Formela, "Utilization of recycled polyethyleneterephthalate (PET) in engineering materials", International Journal of EnvironmentalScience and Development, Vol. 7, Issue 2, February 2015,pp: 100-108
[6] K. G. Devaki, "Investigation to increases the strength and workability of concrete byusing bottle caps with admixture" IOSR Journal of Mechanical and Civil Engineering,Vol. 11, Issue 2, Mar- Apr. 2014, pp: 28-31

[7] R. N. Nibudey and Dr. P. B. Nagarnaik, "Strengths prediction of plastic fiber reinforcedconcrete (M30)", International Journal of Engineering Research and Applications(IJERA), Vol. 3, Issue 1, January February 2013, pp: 1818-1825

[8] "Concrete Technology", M.S Shetty

[9] IS 456: 2000, "Indian standard code of practice for plain and reinforced concrete", Bureauof Indian standard, NewDelhi

[10] IS 10262:2009, "Recommended Guidelines for concrete mix design", Bureau ofIndian standard, New Delhi

[11] IS 383: 1970, "Specification for Coarse aggregate and Fine aggregate from NaturalSources for Concrete", Bureau of Indian Standard, New Delhi

[12] IS 5816: 1999, "Splitting Tensile Strength of Concrete Method of Test", Bureau of Indian Standard, New Delhi 